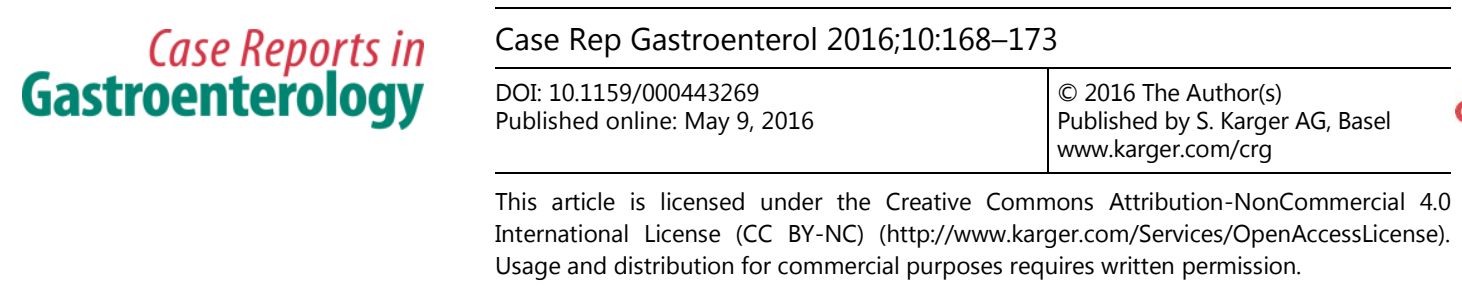

\title{
A Case of Gastrointestinal Stromal Tumor That Underwent Endoscopic Ultrasound-Guided Aspiration with a 25-Gauge Biopsy Needle
}

\author{
Minoru Tomizawa $^{a} \quad$ Fuminobu Shinozaki $^{\mathrm{b}} \quad$ Yasufumi Motoyoshi $^{\mathrm{c}}$ \\ Takao Sugiyama $^{d}$ Shigenori Yamamoto ${ }^{e}$ Naoki Ishige $^{f}$ \\ ${ }^{a}$ Department of Gastroenterology, National Hospital Organization, Shimoshizu Hospital, \\ Yotsukaido, Japan; ${ }^{b}$ Department of Radiology, National Hospital Organization, Shimoshizu \\ Hospital, Yotsukaido, Japan; 'Department of Neurology, National Hospital Organization, \\ Shimoshizu Hospital, Yotsukaido, Japan; ${ }^{\text {d}}$ Department of Rhuematology, National Hospital \\ Organization, Shimoshizu Hospital, Yotsukaido, Japan; ${ }^{\mathrm{e} D e p a r t m e n t}$ of Pediatrics, \\ National Hospital Organization, Shimoshizu Hospital, Yotsukaido, Japan; ${ }^{f}$ Department of \\ Neurosurgery, National Hospital Organization, Shimoshizu Hospital, Yotsukaido, Japan
}

\section{Keywords}

$\mathrm{KIT} \cdot \mathrm{CD} 117 \cdot \mathrm{CD} 34 \cdot \mathrm{Ki}-67 \cdot$ Color Doppler $\cdot$ Submucosal tumor

\begin{abstract}
Endoscopic ultrasound-guided fine needle aspiration (EUS-FNA) is performed to obtain specimens for pathological analysis. For this procedure, 19-gauge (19G), 22-guage (22G), and 25guage $(25 \mathrm{G})$ needles are available. The needles are classified into aspiration type and biopsy type. A 56-year-old woman underwent upper gastrointestinal endoscopy that showed a 38$\mathrm{mm}$-diameter submucosal tumor. The elevated lesion was diagnosed as a submucosal tumor of the stomach. Contrast-enhanced computed tomography showed a low-density area on the luminal surface of the gastric wall, which was covered with a thin layer of gastric mucosa. EUS showed a hypoechoic lesion in the submucosal layer. Color Doppler image showed a pulsating vascular signal extending into the center of the hypoechoic lesion from the periphery. EUS-FNA was performed with a $25 \mathrm{G}$ biopsy needle. The specimen tissue consisted of
\end{abstract}




\section{Case Reports in Gastroenterology}

Case Rep Gastroenterol 2016;10:168-173

(c) 2016 The Author(s). Published by S. Karger AG, Basel www.karger.com/crg

Tomizawa et al: A Case of Gastrointestinal Stromal Tumor That Underwent Endoscopic Ultrasound-Guided Aspiration with a 25-Gauge Biopsy Needle

spindle-shaped cells. The cells were positive for CD117 and CD34. The submucosal tumor was diagnosed as a gastrointestinal stromal tumor.

(C) 2016 The Author(s)

Published by S. Karger AG, Basel

\section{Introduction}

Gastrointestinal stromal tumor (GIST) is a gastric submucosal tumor (SMT), originating from the interstitial cells of Cajal. Around $40 \%$ of GISTs occur in the stomach. Gastric GIST is treated with surgery, including laparoscopy, endoscopic mucosal resection, or endoscopic submucosal dissection, and imatinib is also used for the treatment of GIST [1].

For appropriate treatment, prompt and precise diagnosis of GIST is essential. There are several markers that are useful for the diagnosis of GIST, such as CD34, CD117, and Ki-67 [2]. KIT gene mutation is a feature of GIST, and patients with GIST, along with KIT gene mutation, have a poor prognosis [3]. CD34, a marker of hematopoietic progenitor cells, is expressed in GIST [2]. Ki-67 is involved in cell proliferation, and its high expression correlates with poor prognosis of GIST. To exert the above analysis, a sampling of specimens is important.

Endoscopic ultrasound (EUS) is useful for the morphological investigation of gastric GIST [4]. Contrast-enhanced EUS provides more information for the evaluation of gastric SMT [5]. EUS-guided fine needle aspiration (EUS-FNA) enables histological evaluation, leading to the pathological diagnosis of gastric GIST [6]. EUS-FNA has the potential of diagnosing GIST at molecular levels [7]. There are three sizes of needles available for this procedure: 19gauge (19G), 22-guage (22G), and 25-guage (25G) [8]. Based on the method of specimen collection, the needles are classified into aspiration type and biopsy type [8]. Aspiration needles are used to acquire specimens by aspirating tissues into the lumen of the outer sheath, while biopsy needles are used to cut specimens that are aspirated into the lumen of the needle [9].

Here, we report a case of gastric GIST diagnosed with specimens obtained by EUS-FNA with a $25 \mathrm{G}$ biopsy needle.

\section{Case Presentation}

A 56-year old woman underwent screening with upper gastrointestinal endoscopy (GIFXRQ260; Olympus, Tokyo, Japan). Endoscopy showed an elevated gastric mucosa (fig. 1a). The elevated lesion was covered with normal gastric mucosa. The diameter of the elevated lesion was $38 \mathrm{~mm}$. The elevated lesion was diagnosed as a submucosal tumor of the stomach. Contrast-enhanced computed tomography (SOMATOM Emotion 16; SIEMENS, Munich, Germany) was performed for further analysis of the submucosal tumor (fig. 1b). A lowdensity area was seen on the luminal surface of the stomach. The low-density area was covered with a thin layer of gastric mucosa.

For further investigation of the submucosal tumor, EUS was performed (GF-UCT260; Olympus). A hypoechoic lesion with a clear margin was seen (fig. 2a). The low-echo lesion existed in the submucosal layer. Color Doppler image showed a pulsating vascular signal extending into the center of the low-echo lesion from the periphery. EUS-FNA was performed for pathological evaluation of the submucosal tumor with a 25G biopsy needle (ECHO-HD-25c, Cook Medical Inc., Bloomington, Ind., USA) (fig. 2B). EUS-FNA was completed safely without any complications. 
A fragment of tissue was obtained from the clot and was stained using hematoxylin and eosin (fig. 3a). The tissue specimen consisted of spindle-shaped cells. There was a possibility that these spindle-shaped cells were gastrointestinal stromal tumor or leiomyoma cells. Immunostaining was performed for pathological diagnosis. No signal was observed on immunostaining with antit-S100, a marker of nerve cells (fig. 3B) or anti- $\alpha$ smooth muscle actin, a marker of smooth muscle cells (fig. 3c). Approximately 3\% of the cells were positive for Ki-67 (fig. 3d). The cells were strongly positive for anti-CD34 (fig. 3e) and anti-CD117 (fig. $3 \mathrm{f}$ ). The submucosal tumor was diagnosed as GIST. The case was referred to another hospital for treatment.

\section{Discussion}

EUS-FNA is an established and relatively safe technique, with virtually no complications [10]. There are two types of needles available for EUS-FNA: aspiration type and biopsy type [8]. One major limitation of EUS-FNA with the aspiration needle is that the acquired specimens are sometimes fragmented and not suitable for pathological analysis such as immunostaining [11]. The 19G biopsy needle is used to cut specimens that are aspirated into the lumen of the needle [9]. This 19G biopsy needle in EUS-FNA can obtain enough specimens for pathological analysis compared to a $22 \mathrm{G}$ aspiration needle [12]. Potential complications associated with the used of the 19G biopsy needle are bleeding and perforation [13]. Strand et al. [14] compared the $22 \mathrm{G}$ aspiration needle and the $22 \mathrm{G}$ biopsy needle. They concluded that the $22 \mathrm{G}$ biopsy needle is more suitable to obtain enough specimens for pathological analysis. In our case, the 25G biopsy needle was used. The obtained specimens were adequate for pathological investigation including immunostaining without any complications. Our data suggested that the $25 \mathrm{G}$ needle was adequate to obtain specimens for pathological analysis. The $22 \mathrm{G}$ or $25 \mathrm{G}$ aspiration needle is used for gastric SMTs less than $10 \mathrm{~mm}$ in size [15]. It was expected that the $25 \mathrm{G}$ biopsy needle would be useful to obtain specimens suitable for pathological analysis, with fewer complications even from a small gastric SMT.

In conclusion, it was found that a 25G biopsy needle was suitable for EUS-FNA of gastric GIST.

\section{Statement of Ethics}

This report was approved by the National Hospital Organization Shimoshizu Hospital Ethics Committee. It was not assigned as a clinical trial, but was considered a part of daily clinical practice. Written informed consent for this report was obtained from the patient. Patient records were anonymously and retrospectively analyzed. Written informed consent was obtained for upper gastrointestinal endoscopy, contrast-enhanced computed tomography, EUS, and EUS-FNA.

\section{Disclosure Statement}

The authors have no conflicts of interest to declare. 


\section{Case Reports in \\ Gastroenterology}

\section{References}

1 Nishida T, Kawai N, Yamaguchi S, Nishida Y: Submucosal tumors: comprehensive guide for the diagnosis and therapy of gastrointestinal submucosal tumors. Dig Endosc 2013;25:479-489.

2 Kim IH, Kwak SG, Chae HD: Prognostic factors of patients with gastric gastrointestinal stromal tumor after curative resection: a retrospective analysis of 406 consecutive cases in a multicenter study. Eur Surg Res 2015;55:12-23.

-3 Rossi JM, Dunn NR, Hogan BL, Zaret KS: Distinct mesodermal signals, including BMPs from the septum transversum mesenchyme, are required in combination for hepatogenesis from the endoderm. Genes Dev 2001;15:1998-2009.

-4 Chen TH, Hsu CM, Chu YY, Wu CH, Chen TC, Hsu JT, Yeh TS, Lin CJ, Chiu CT: Association of endoscopic ultrasonographic parameters and gastrointestinal stromal tumors (GISTs): can endoscopic ultrasonography be used to screen gastric GISTs for potential malignancy? Scand J Gastroenterol 2016;51:374-377.

-5 Kannengiesser K, Mahlke R, Petersen F, Peters A, Ross M, Kucharzik T, Maaser C: Contrast-enhanced harmonic endoscopic ultrasound is able to discriminate benign submucosal lesions from gastrointestinal stromal tumors. Scand J Gastroenterol 2012;47:1515-1520.

-6 Lee JH, Cho CJ, Park YS, Ahn JY, Kim DH, Na HK, Choi KD, Song HJ, Lee GH, Jung HY: EUS-guided 22gauge fine needle biopsy for the diagnosis of gastric subepithelial tumors larger than $2 \mathrm{~cm}$. Scand J Gastroenterol 2015, Epub ahead of print

-7 Gleeson FC, Kipp BR, Kerr SE, Voss JS, Graham RP, Campion MB, Minot DM, Tu ZJ, Klee EW, Lazaridis KN, Henry MR, Levy MJ: Kinase genotype analysis of gastric gastrointestinal stromal tumor cytology samples using targeted next-generation sequencing. Clin Gastroenterol Hepatol 2015;13:202-206. Tharian B, Tsiopoulos F, George N, Pietro SD, Attili F, Larghi A: Endoscopic ultrasound fine needle aspiration: technique and applications in clinical practice. World J Gastrointest Endosc 2012;4:532544.

-9 Iglesias-Garcia J, Abdulkader I, Larino-Noia J, Dominguez-Munoz JE: Evaluation of the adequacy and diagnostic accuracy of the histology samples obtained with a newly designed 19-gauge EUS histology needle. Rev Esp Enferm Dig 2014;106:6-14.

10 Ito H, Inoue H, Ryozawa S, Ikeda H, Odaka N, Eleftheriadis N, Maselli R, Sando N, Kimura S, Kudo SE: Fine-needle aspiration biopsy and endoscopic ultrasound for pretreatment pathological diagnosis of gastric gastrointestinal stromal tumors. Gastroenterol Res Pract 2012;2012:139083.

-11 Kim GH, Cho YK, Kim EY, Kim HK, Cho JW, Lee TH, Moon JS: Comparison of 22-gauge aspiration needle with 22-gauge biopsy needle in endoscopic ultrasonography-guided subepithelial tumor sampling. Scand J Gastroenterol 2014;49:347-354.

-12 Na HK, Lee JH, Park YS, Ahn JY, Choi KS, Kim do H, Choi KD, Song HJ, Lee GH, Jung HY, Kim JH: Yields and utility of endoscopic ultrasonography-guided 19-gauge Trucut biopsy versus 22-gauge fine needle aspiration for diagnosing gastric subepithelial tumors. Clin Endosc 2015;48:152-157.

13 Hamada T, Yasunaga H, Nakai Y, Isayama H, Horiguchi H, Matsuda S, Fushimi K, Koike K: Rarity of severe bleeding and perforation in endoscopic ultrasound-guided fine needle aspiration for submucosal tumors. Dig Dis Sci 2013;58:2634-2638.

14 Strand DS, Jeffus SK, Sauer BG, Wang AY, Stelow EB, Shami VM: EUS-guided 22-gauge fine-needle aspiration versus core biopsy needle in the evaluation of solid pancreatic neoplasms. Diagn Cytopathol 2014;42:751-758.

15 Yamabe A, Irisawa A, Bhutani MS, Shibukawa G, Abe Y, Saito A, Imbe K, Hoshi K, Igarashi R: Usefulness of endoscopic ultrasound-guided fine-needle aspiration with a forward-viewing and curved lineararray echoendoscope for small gastrointestinal subepithelial lesions. Endosc Int Open 2015;3:E161E164. 


\section{Case Reports in Gastroenterology}

\begin{tabular}{l|l}
\hline Case Rep Gastroenterol 2016;10:168-173 \\
\hline $10.1159 / 000443269$ & $\begin{array}{l}\text { ○ 2016 The Author(s). Published by S. Karger AG, Basel } \\
\text { www.karger.com/crg }\end{array}$ \\
\hline
\end{tabular}

Tomizawa et al.: A Case of Gastrointestinal Stromal Tumor That Underwent Endoscopic Ultrasound-Guided Aspiration with a 25-Gauge Biopsy Needle
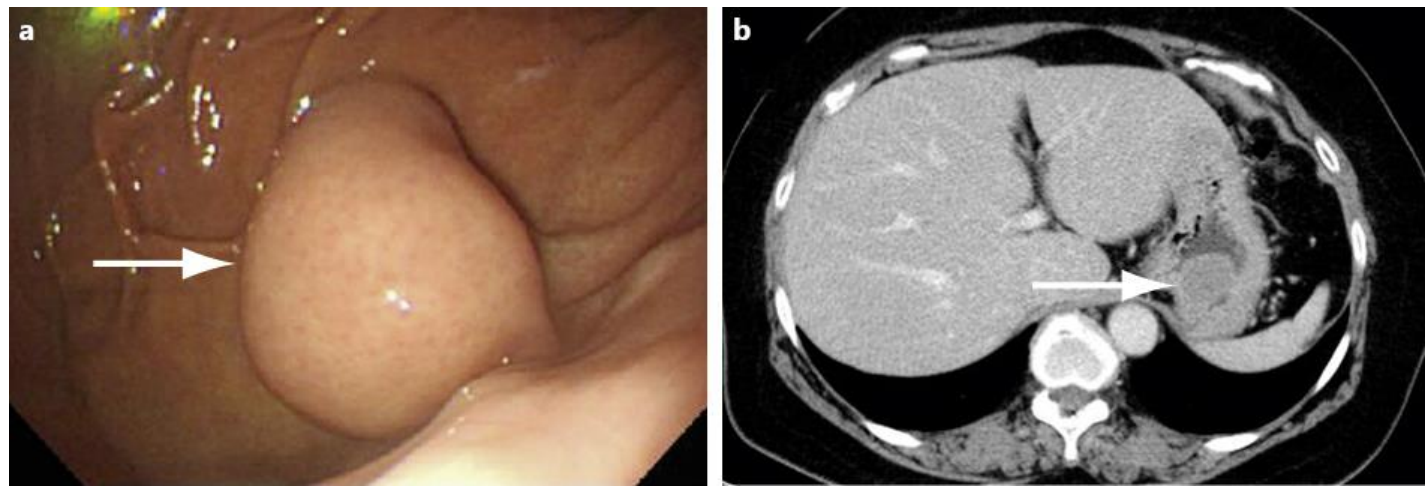

Fig. 1. GIST presenting as a SMT of the stomach. a Upper gastrointestinal endoscopy shows a SMT of the stomach, $38 \mathrm{~mm}$ in diameter. b Contrast-enhanced computed tomography shows a slightly low-density area on the internal surface of the gastric wall compared to that of the adjacent wall.
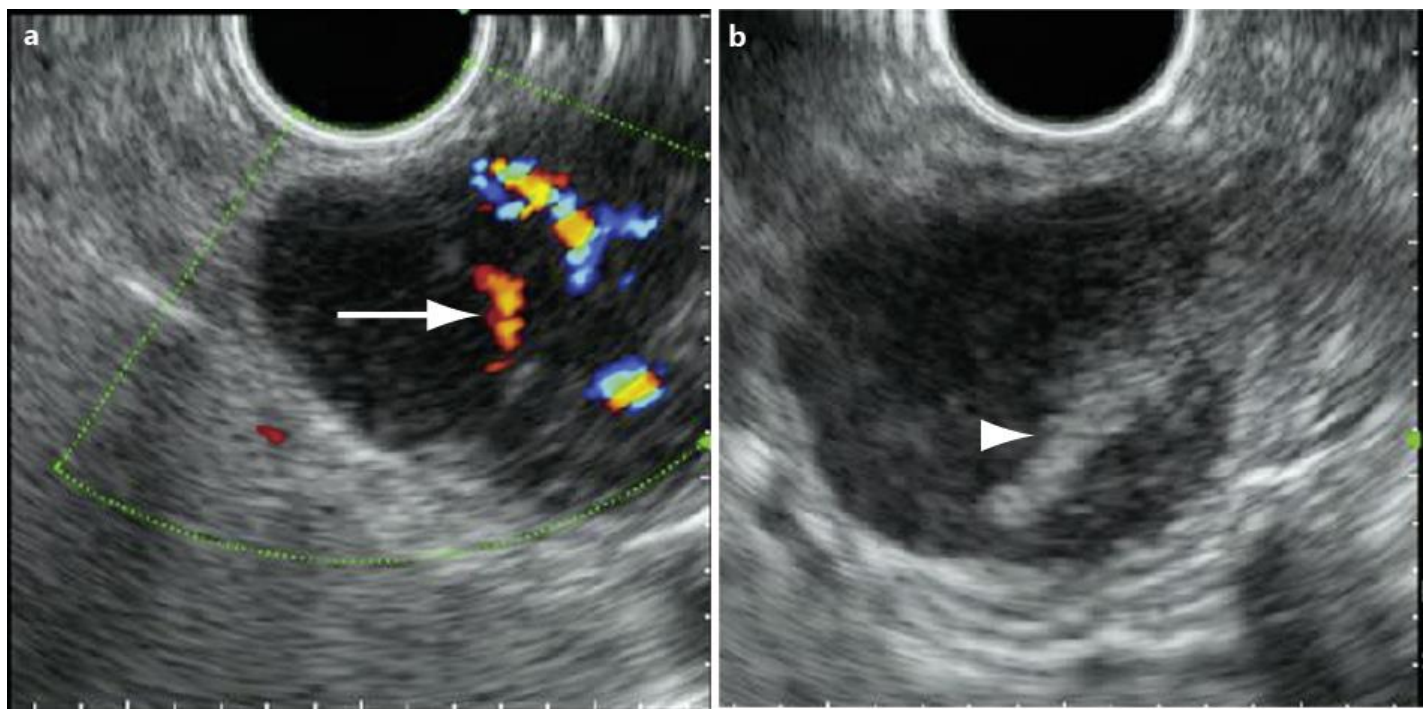

Fig. 2. a EUS shows a low-echo lesion, $3.5 \mathrm{~cm}$ in diameter. Color Doppler image shows a vascular signal extending into the center (arrow). b 22G EUS-FNA was performed (arrowhead). 


\section{Case Reports in Gastroenterology

\begin{tabular}{l|l}
\hline Case Rep Gastroenterol 2016;10:168-173 \\
\hline $10.1159 / 000443269$ & $\begin{array}{l}\text { C 2016 The Author(s). Published by S. Karger AG, Basel } \\
\text { www.karger.com/crg }\end{array}$ \\
\hline
\end{tabular} \\ Tomizawa et al.: A Case of Gastrointestinal Stromal Tumor That Underwent Endoscopic Ultrasound-Guided Aspiration with a 25-Gauge Biopsy Needle}
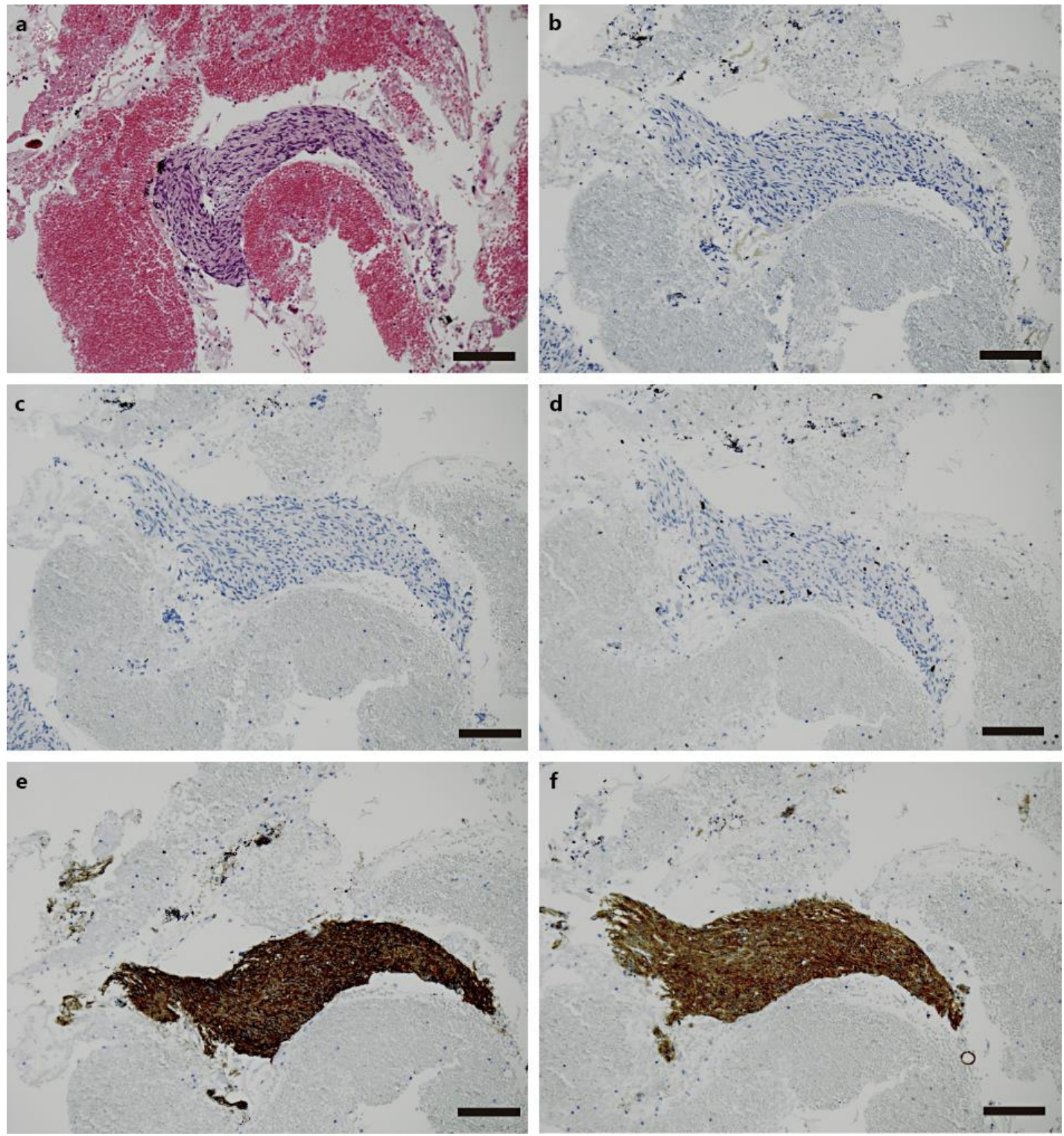

Fig. 3. Histological analysis of EUS-FNA cytology specimens. Hematoxylin and eosin staining (a), S100 (b), $\alpha$-smooth muscle actin (c), Ki-67 (d), CD34 (e), CD117 (f). Original magnification: $\times 200$. Scale bars $=100$ $\mu \mathrm{m}$. 